\title{
Partisipasi Politik Pemilih Pemula Dalam Pemilihan Umum Legislatif Tahun 2014 di Kelurahan Panyanggar Kecamatan Padangsidimpuan Utara Kota Padangsidimpuan
}

\author{
Tri Eva Juniasih
}

Universitas Graha Nusantara, Email : trievajuniasih@gmail.com

\begin{abstract}
Abstrak
Pemilihan umum merupakan salah satu bentuk partisipasi politik sebagai perwujudan dari kedaulatan rakyat, karena saat pemilihan umum itulah rakyat menjadi pihak yang paling menentukan bagi proses politik untuk memilih wakilwakilnya dengan memberikan suara secara langsung. Kesadaran politik merupakan faktor penentu dalam partisipasi politik masyarakat.

Tujuan penelitian ini adalah untuk mengetahui bagaimana partisipasi pemilih pemula dalam pemilihan umum legislatif tahun 2014 di Kelurahan Panyanggar Kecamatan Padangsidimpuan Utara Kota Padangsidimpuan. Penelitian ini menggunakan metode deskriptif kualitatif yang bertujuan untuk memecahkan, menjawab dan menggambarkan manfaat yang menitikberatkan pada kajian mengenai partisipasi politik pemilih pemula dalam pemilihan umum legislatif tahun 2014 di Kelurahan Panyanggar Kecamatan Padangsidimpuan Utara Kota Padangsidimpuan.

Dari hasil penelitian yang dilakukan, bahwa pemilih pemula sangat antusias untuk ikut berpartisipasi menggunakan hak pilihnya dalam pemilihan umum legislatif tahun 2014. Tingkat partisipasi pemilih pemula dalam pemilihan umum legislatif tahun 2014 yaitu dalam menggunakan hak pilihnya dilakukan $94,3 \%$.

Kata Kunci : Partisipasi Politik, Pemilih Pemula

General elections are a form of political participation as a manifestation of popular sovereignty, because it is during the general election that the people become the most decisive party for the political process to elect their representatives by voting directly. Political awareness is a determining factor in people's political participation.

The purpose of this study was to find out how the participation of early voters in the 2014 legislative elections in Panyanggar Village, Padangsidimpuan Utara Subdistrict, Padangsidimpuan City. This research uses descriptive qualitative method which aims to solve, answer and describe the benefits that focus on the study of the voter political participation in the 2014 legislative elections in Panyanggar Village, Padangsidimpuan Utara District, Padangsidimpuan City.

From the results of the research conducted, that novice voters were very enthusiastic to participate using their voting rights in the 2014 legislative elections. The level of participation of first-time voters in the 2014 legislative elections in using their voting rights was $94.3 \%$.
\end{abstract}

Keywords: Political Participation, Beginner Voters

\section{PENDAHULUAN}

Pemilu secara langsung oleh rakyat merupakan perwujudan kedaulatan rakyat guna menghasilkan pemerintahan negara yang demokratis berdasarkan Pancasila dan Undang-Undang Dasar Republik Indonesia tahun 1945. Penyelenggaraan pemilu secara langsung, umum, bebas, rahasia, jujur, dan adil dapat terwujud apabila dilaksanakan oleh penyelenggara 


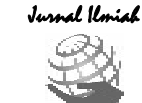 \\ menome}

pemilu yang mempunyai integritas, profesionalitas, dan akuntabilitas

Menurut Undang-Undang Republik Indonesia Nomor 15 tahun 2011 tentang Penyelenggaraan Pemilu dijelaskan pengertian pemilu: "adalah sarana kedaulatan rakyat yang dilaksanakan secara langsung, umum, bebas, rahasia, jujur, dan adil dalam Negara Kesatuan Republik Indonesia tahun 1945". Pemilu legislatif adalah pemilu yang diselenggarakan untuk memilih anggota Dewan Perwakilan Rakyat, Dewan Perwakilan Daerah, Dewan Perwakilan Rakyat Daerah Provinsi, Dewan Perwakilan Rakyat Daerah Kab/Kota sebagai sarana kedaulatan rakyat untuk menghasilkan wakil rakyat yang aspiratif, berkualitas, dan bertanggungjawab berdasarkan Pancasila dan Undang-Undang Dasar tahun 1945.

Partisipasi merupakan salah satu aspek penting dari demokrasi. Asumsi yang mendasari demokrasi partisipasi merupakan orang yang paling tahu tentang apa yang baik bagi dirinya adalah orang itu sendiri. Karena keputusan yang politik yang dibuat dan dilaksanakan oleh pemerintah menyangkut dan mempengaruhi kehidupan warga negara, maka warga negara berhak ikut serta menentukan isi keputusan yang mempengaruhi hidupnya.

Kesadaran politik merupakan faktor penentu dalam partisipasi politik masyarakat, artinya hal yang berhubungan dengan pengetahuan dan kesadaran akan hak dan kewajiban yang berkaitan dengan lingkungan masyarakat dan kegiatan politik menjadi ukuran seseorang terlibat dalam proses partisipasi politik tersebut. Pengalaman pemilu yang berlangsung dalam beberapa dekade menunjukkan banyaknya para pemilih yang tidak memberikan suaranya. Hal ini merupakan gambaran bahwa apabila seseorang memiliki kesadaran politik dan kepercayaan kepada pemerintah tinggi maka partisipasi politik cenderung aktif, sedangkan apabila kesadaran politik dan kepercayaan kepada pemerintah sangat kecil, maka partisipasi politik menjadi pasif dan apatis.

Berdasarkan data dari Komisi Pemilihan Umum (KPU) jumlah total pemilih yang terdaftar untuk pemilu tahun 2014 adalah sejumlah 186.612.255 orang penduduk Indonesia. Dari jumlah tersebut sekitar 20-30 persen adalah pemilih pemula yang terdiri dari siswa SMA dan mahasiswa.

Secara politis pemilih pemula memang lebih sedikit dibanding dengan pemilih yang lain, tetapi ini merupakan sebuah penggambaran bagaimana partisipasi mereka kedepannya, walaupun secara politis suara dari pemilih pemula tidak dapat mempengaruhi hasil perolehan akhir suara, tetapi tidak bisa dipungkiri bahwa partai politik juga memerlukan suara mereka untuk menambah perolehan suaraa yang telah ada, sebab tujuan dari partai politik dalam sebuah pemilihan adalah untuk dapat memperoleh suara sebanyakbanyaknya.

Secara psikologis, karakteristik pemilih pemula berbeda dengan orangorang tua pada umumnya, pemilih pemula cenderung kritis, mandiri, independen, pro perubahan dan sebagainnya. Karakteristik itu cukup kondusif untuk membangun komunitas pemilih yang cerdas dalam pemilu yakni pemilih yang memiliki pertimbangan rasional dalam menentukan pilihannya. Misalnya karena integritas tokoh yang dicalonkan partai politik, pencapaian kerja atau program kerja yang ditawarkan.

Selain memiliki kelebihan, pemilih pemula juga memiliki kekurangan yakni belum memiliki pengalaman dalam pemilu, pada umumnya banyak dari kalangan mereka belum mengetahui berbagai hal yang terkait dengan pemilu dan tidak tahu bahwa suaranya sangat berarti bagi proses politik di negaranya. Bahkan tidak jarang mereka enggan berpartisipasi dalam pemilu dan memilih ikut-ikutan tidak mau menggunakan hak pilihnya alias golongan putih (golput).

Karena belum punya pengalaman memilih dalam pemilu, pemilih pemula perlu mengetahui dan memahami berbagai hal yang terkait dengan pemilu. Misalnya untuk apa pemilu diselenggarakan, apa saja tahapan pemilu, siapa saja yang boleh ikut serta dalam pemilu, bagaimana tata cara menggunakan hak pilih dalam pemilu dan sebagainya. Pertanyaan itu penting diajukan agar pemilih pemula menjadi pemilih cerdas dalam menentukan pilihan politiknya di setiap pemilu. 


\section{Jarnal Ilmiah \\ MUQODDIMAH}

Kelurahan Panyanggar yang terletak di Kecamatan Padangsidimpuan Utara merupakan wilayah yang memiliki kewajiban untuk menyelenggarakan kegiatan pemilu secara serentak dengan daerah-daerah lainnya sesuai dengan Undang-Undang demi mensukseskan demokrasi di negeri ini. Berdasarkan hasil observasi yang dilakukan pada hari pemungutan suara di Kelurahan Panyanggar menunjukkan bahwa angka partisipasi pemilih pemula yang ikut memberikan suaranya dalam pemilu legislatif tahun 2014 sebesar 93,4 \% dari jumlah pemilih pemula yang terdaftar di Daftar Pemilih Tetap (DPT) sebanyak 122 orang.

Hal tersebut menggambarkan bahwa partisipasi politik pemilih pemula di Kelurahan Panyanggar pada pemilu legislatif tahun 2014 terlihat cukup tinggi walaupun sebagian besar dari pemilih pemula belum memiliki jangkauan politik yang luas untuk menentukan kemana mereka harus memilih. Selain itu, ketidaktahuan dalam soal politik membuat pemilih pemula lebih memikirkan kepentingan jangka pendek, sehingga terkadang apa yang mereka pilih tidak sesuai dengan yang diharapkan.

\section{Batasan Masalah}

Untuk memberikan gambaran yang lebih jelas menyangkut ruang lingkup dan fokus penelitian serta agar penelitian ini tidak mengambang maka penulis membatasi penelitian ini hanya pada Partisipasi Politik Pemilih Pemula Dalam Pemilihan Umum Legislatif Tahun 2014 Di Kelurahan Panyanggar Kecamatan Padangsidimpuan Utara Kota Padangsidimpuan.

\section{Perumusan Masalah}

Berdasarkan latar belakang yang telah diuraikan di atas, maka penulis merumuskan masalah pada "Bagaimana partisipasi politik pemilih pemula dalam pemilihan umum legislatif tahun 2014 di Kelurahan Panyanggar Kecamatan Padangsidimpuan Utara Kota Padangsidimpuan.

\section{Tujuan}

Adapun tujuan dari penelitian ini adalah "Untuk mengetahui bagaimana partisipasi pemilih pemula dalam pemilu legislatif tahun 2014 di Kelurahan Panyanggar Kecamatan Padangsidimpuan Utara Kota Padangsidimpuan."

\section{Kajian Teoritis \\ Pengertian Partai Politik}

Menurut Undang-Undang Nomor 2 Tahun 2011 tentang Partai Politik menyebutkan bahwa, "partai politik adalah organisasi yang besifat nasional dan dibentuk oleh sekelompok warga negara Indonesia secara sukarela atas dasar kesamaan kehendak dan cita-cita untuk memperjuangkan dan membela kepentingan politik anggota, masyarakat, bangsa dan negara serta memelihara keutuhan negara Kesatuan Republik Indonesia berdasarkan Pancasila dan Undang-Undang Dasar Negara Republik Indonesia tahun 1945"

Menurut Miriam Budiarjo "secara umum dapat dikatakan bahwa partai politik adalah suatu kelompok terorganisir yang anggotanya mempunyai orientasi, nilainilai, dan cita-cita yang sama. Tujuan kelompok ini ialah untuk memperoleh kekuasaan politik dan merebut kedudukan politik biasanya dengan cara konstitusional untuk melaksanakan programnya". (2008:403)

\section{Fungsi Partai Politik}

Adapun fungsi partai politik adalah sebagai berikut:

a. Sebagai Sarana Komunikasi Politik

b. Sebagai Sarana Sosialisasi Politik

c. Sebagai Sarana Rekrutmen Politik

d. Sebagai Sarana Partisipasi Politik

e. Sebagai Sarana Pengatur Konflik (Antonius Sitepu,2012:189)

\section{Partisipasi Politik}

Partisipasi politik pada dasarnya merupakan kegiatan yang dilakukan warga negara untuk terlibat dalam proses pengambilan keputusan dengan tujuan untuk mempengaruhi pengambilan keputusan yang dilakukan oleh pemerintah. Menurut Miriam 
Budiarjo, partisipasi politik adalah "kegiatan seseorang atau sekelompok orang untuk ikut serta secara aktif dalam kehidupan politik, dengan jalan memilih pimpinan negara dan secara langsung atau tidak langsung mempengaruhi kebijakan pemerintah (public policy)". (Miriam Budiarjo, 2008:403) Menurut Herbert McClosky dalam Miriam Budiarjo menyebutkan bahwa, Partisipasi politik adalah kegiatan-kegiatan sukarela dari warga masyarakat melalui mana mereka mengambil bagian dalam proses pemilihan penguasa, dan secara langsung atau tidak langsung, dalam proses pembentukan kebijakan umum.(2008:367)

Pendapat lain dikemukakan oleh P. Antonius Sitepu sebagai berikut: Partisipasi politik adalah kegiatan yang dilakukan warga negara biasa dalam mempengaruhi proses pembuatan dan pelaksanaan kebijakan umum dan ikut serta dalam menentukan pemimpin pemerintahan. Kegiatan yang dimaksud antara lain mengajukan tuntutan, membayar pajak, melaksanakan keputusan, mengajukan kritik dan koreksi atas pelaksanaan suatu kebijakan umum, mendukung dan menentang calon pemimpin tertentu, mengajukan alternatif pemimpin dan memilih wakil rakyat dalam pemilu.(2012: 191).

Sedangkan menurut Anwar Arifin bahwa: Partisipasi politik ialah keterlibatan individu-individu dalam bermacam-macam tindakan dalam kehidupan politik. Keikutsertaan itu dapat berupa kegiatan memberi atau tidak memberi dukungan politik dalam berbagai kegiatan, terutama dalam kegiatan kampanye dan pemberian suara dalam pemilu serta kegiatan dalam proses penetapan kebijakan politik.(2011: 210)

Dari pengertian partisipasi politik di atas maka dapat ditarik kesimpulan bahwa partisipasi politik adalah sebagai berikut:
1. Partisipasi politik harus berupa kegiatan atau aktivitas langsung maupun tidak langsung.

2. Partisipasi politik yang dimaksud adalah aktivitas politik yang dilakukan warga negara dalam kapasitasnya sebagai dirinya sendiri.

3. Partisipasi politik merupakan kegiatan yang dilakukan secara sadar dalam kehidupan politik dalam rangka mempengaruhi kebijakan pemerintah.

\section{Bentuk partisipasi Politik}

Bentuk partisipasi politik seseorang tampak dalam aktifitas-aktifitas politiknya. Dalam Undang-Undang Republik Indonesia Nomor 8 Tahun 2012 tentang pemilu anggota Dewan Perwakilan Rakyat (DPR), Dewan Perwakilan Daerah (DPD), Dewan Perwakilan Rakyat Daerah (DPRD) pada pasal 264 ayat 2 disebutkan bahwa partisipasi masyarakat dapat dilakukan menjadi empat bentuk, yaitu:

1. Sosialisasi

2. Pendidikan bagi pemilih

3. Survey atau jejak pendapat

4. Penghitungan cepat

Bentuk partisipasi politik yang paling umum dikenal adalah pemungutan suara (voting) untuk memilih calon wakil rakyat atau untuk memilih kepala daerah maupun kepala negara. Menurut Roni Tabroni "Bentuk partisipasi lebih dari itu dapat diwujudkan dalam bentuk pendidikan politik, mengkritisi kebijakan pemerintah, menjadi pengurus partai politik, menjadin tim sukses dari kandidat, menjadi kandidat atau calon legislatif atau kepala daerah dan presiden, hingga menjadi pengambil kebijakan politik".(2012: 28)

Bentuk partisipasi sebenarnya sangat beraneka ragam bukan sekedar berkumpul dalam kegiatan politik, menurut Wahyudi Kumorotomo secara umum corak partisipasi warga negara dapat dibedakan menjadi empat macam yaitu:

1. Partisipasi dalam Pemilihan (electoral participation)

2. Partsipasi Kelompok participation)

(group

3. Kontak antara Warga Negara dengan Pemerintah (citizen-government contacting) 
4. Partisipasi Warga Negara secara Langsung di Lingkungan Pemerintahan. (Wahyudi Kumorotomo, 2008: 136)

\section{Tipologi Partisipasi Politik}

Secara umum tipologi partisipasi sebagai kegiatan dibedakan menjadi:

1. Partisipasi Aktif, yaitu partisipasi yang berorientasi pada proses input dan output. Artinya setiap warga negara secara aktif mengajukan usul-usul mengenai kebijakan publik mengajukan alternatif kebijakan publik yang berlainan dengan kebijakan pemerintah, mengajukan kritik dan perbaikan untuk meluruskan kebijakan umum, memilih pemimpin pemerintah dan lain-lain.

2. Partisipasi Pasif, yaitu partisipasi yang berorientasi hanya pada output, dalam arti hanya menaati peraturan pemerintah, menerima dan melaksanakan saja setiap keputusan pemerintah.

3. Golongan putih (golput) atau kelompok apatis, karena menganggap sistem politik yang ada telah menyimpang dari apa yang dicita-citakan. (A. Rahman, 2007: 288)

\section{Pengertian Pemilu}

Pengertian pemilu menurut Modul Komisi Pemilihan Umum menyebutkan bahwa,Pemilu merupakan sarana pelaksanaan kedaulatan rakyat dimana rakyat dapat memilih pemimpin politik secara langsung. Yang dimaksud dengan pemimpin politik disini adalah wakil-wakil rakyat yang duduk di lembaga perwakilan rakyat (parlemen) baik ditingkat pusat maupun daerah dan pemimpin lembaga eksekutif atau kepala pemerintahan seperti presiden, gubernur, atau bupati/walikota. (KPU,2010: 1)

Menurut Indria Samego dalam A.Rahman H.I meyebutkan bahwa, Pemilu disebut juga dengan "political market",

Berdasarkan ketentuan umum pasal 1 ayat 2 Undang-Undang Republik Indonesia Nomor 8 Tahun 2012 tentang Pemilu Anggota Dewan Perwakilan Rakyat (DPR), Dewan Perwakilan Daerah (DPD), Dewan Perwakilan Rakyat Daerah (DPRD) yang dimaksud dengan Pemilu Anggota DPR, DPD, dan DPRD adalah pemilu untuk memilih anggota DPR, DPD, DPRD provinsi, DPRD kabupaten/kota dalam kesatuan Negara Republik Indonesia berdasarkan Pancasila dan UndangUndang Dasar Negara Republik Indonesia Tahun 1945.

\section{Asas Pemilihan Umum}

Berdasarkan pasal $22 \mathrm{E}$ ayat 1 Undang-Undang Dasar Negara Republik Indonesia Tahun 1945, "pemilu dilaksanakan secara langsung, umum, bebas, rahasia, jujur, dan adil setiap lima tahun sekali”.

\section{Tahapan Pemilu}

Berdasarkan Peraturan Komisi Pemilihan Umum (Nomor 07 tahun 2012 pasal 4 menyebutkan bahwa Tahapan Pemilu Anggota Dewan Perwakilan Rakyat (DPR), Dewan Perwakilan Daerah (DPD), Dewan Perwakilan Rakyat Daerah (DPRD) meliputi :

a. Tahapan persiapan;

b. Tahapan penyelenggaraan; dan

c. Tahapan penyelesaian.

Adapun Tahapan penyelenggaraan pemilu Anggota Dewan Perwakilan Rakyat (DPR), Dewan Perwakilan Daerah (DPD), Dewan Perwakilan Rakyat Daerah (DPRD) adalah sebagai berikut:

a. Pemutakhiran data pemilih dan penyusunan daftar pemilih;

b. Pendaftaran peserta pemilu;

c. Penetapan jumlah kursi dan penetapan daerah pemilihan;

d. Pencalonan anggota DPR, DPD, DPRD Provinsi dan DPRD Kabupaten/kota;

e. Masa kampanye

f. Masa tenang

g. Pemungutan dan penghitungan suara;

h. Penetapan hasil pemilu anggota DPR, DPD, DPRD Provinsi dan DPRD kabupaten/kota;

i. Pengucapan sumpah/janji anggota DPR, DPD, DPRD Provinsi dan DPRD Kabupaten/kota terpilih. (KPU, 2010: 18)

\section{Sistem Pemilu}

Dalam ilmu politik dikenal bermacam-macam sistem pemilu dengan berbagai variasinya, akan tetapi 
umumnya berkisar pada dua prinsip pokok, yaitu:

a. Single-meber Constituency (satu daerah pemilihan memilih satu wakil, biasanya disebut sistem distrik).

b. Multi-member Constituency (satu daerah pemilihan memilih beberapa wakil), biasanya dinamakan Sistem Perwakilan Berimbang atau Sistem Proporsional. (Miriam Budiarjo, 2008: 462)

Menurut Anwar Arifin secara garis besar sistem pemilu dapat dibagi menjadi dua yaitu sistem proporsional dan sistem non proporsional yang dikenal juga dengan sebutan sistem distrik. (2011: 220)

\section{Pemilih Pemula}

Menurut Undang-Undang Republik Indonesia Nomor 8 Tahun 2012 tentang Pemilu anggota Dewan Perwkilan Rakyat, Dewan Perwakilan Daerah, Dewan Perwakilan Rakyat Daerah pasal 1 ayat 25 menyebutkan bahwa,

Pemilih adalah Warga Negara Indonesia yang telah genap berumur 17 tahun atau lebih dan atau sudah/pernah kawin mempunyai hak memilih. Dan pasal 19 ayat 2, "Warga Negara Indonesia sebagaimana dimaksud dalam pasal 19 ayat 1 didaftar oleh penyelenggara pemilu dalam daftar pemilih.

Sebagaimana dijelaskan pula dalam Modul Komisi Pemilihan Umum (KPU) bahwa,

Pemilih Pemula adalah pemilih yang baru pertama kali akan melakukan penggunaan hak pilihnya. Pemilih pemula terdiri dari masyarakat yang telah memenuhi syarat untuk memilih. Adapun syarat-syarat yang harus dimiliki untuk menjadikan seseorang dapat memilih adalah:

1. Umur sudah 17 tahun;

2. Sudah / pernah kawin; dan

3. Purnawirawan / sudah tidak lagi menjadi anggota TNI / Kepolisian

Dari uraian diatas dapat disimpulkan bahwa pemilih pemula adalah warga negara Indonesia berusia 17 tahun dan sudah/pernah kawin yang di daftar penyelenggara pemilu dalam daftar pemilih dan baru mengikuti (memberikan suara) pertama kali dalam pemilu.

\section{Jenis Penelitian}

Dalam penilitian ini, penulis menggunakan penilitian deskriptif kualitatif. Menurut Sugiyono penelitian deskriptif adalah penelitian yang dilakukan untuk mengetahui nilai variabel mandiri, baik satu variabel atau lebih tanpa membuat perbandingan.

\section{Informan Penelitian}

Adapun yang menjadi informan dalam penelitian ini adalah pemilih pemula yang berusia 17 tahun yang terdaftar dalam Daftar Pemilih Tetap (DPT) di Kelurahan Panyanggar yaitu sebagai berikut:

Tabel 3.1. Informan Penelitian

\begin{tabular}{|c|c|c|c|c|c|}
\hline $\begin{array}{l}N \\
0\end{array}$ & Nama & $\begin{array}{c}\text { Jenis } \\
\text { Kelami } \\
n\end{array}$ & Usia & $\begin{array}{l}T \\
P \\
S\end{array}$ & Ket. \\
\hline 1 & $\begin{array}{l}\text { Muktar Helmi, } \\
\text { S.Pd.I }\end{array}$ & $\begin{array}{l}\text { Laki- } \\
\text { laki }\end{array}$ & $\begin{array}{c}35 \\
\text { tahu } \\
n\end{array}$ & - & $\begin{array}{c}\text { Anggota } \\
\text { KPU (Divisi } \\
\text { Sosialisasi, } \\
\text { Pendidikan } \\
\text { Pemilih dan } \\
\text { Pengemba } \\
\text { ngan SDM) }\end{array}$ \\
\hline 2 & Evi Harahap & $\begin{array}{l}\text { Perem } \\
\text { puan }\end{array}$ & $\begin{array}{c}26 \\
\text { tahu } \\
n\end{array}$ & - & $\begin{array}{l}\text { Anggota } \\
\text { PPS }\end{array}$ \\
\hline 3 & $\begin{array}{l}\text { Milfa Suryani } \\
\text { Harahap }\end{array}$ & $\begin{array}{l}\text { Perem } \\
\text { puan }\end{array}$ & $\begin{array}{c}26 \\
\text { tahu } \\
n\end{array}$ & - & $\begin{array}{c}\text { Anggota } \\
\text { KPPS }\end{array}$ \\
\hline 4 & $\begin{array}{l}\text { Nur Asiah } \\
\text { Harahap }\end{array}$ & $\begin{array}{l}\text { Perem } \\
\text { puan }\end{array}$ & $\begin{array}{c}17 \\
\text { tahu } \\
\mathrm{n}\end{array}$ & II & $\begin{array}{l}\text { Pemilih } \\
\text { pemula }\end{array}$ \\
\hline 5 & $\begin{array}{l}\text { Edo Salsabila } \\
\text { Nasution }\end{array}$ & $\begin{array}{l}\text { Laki- } \\
\text { laki }\end{array}$ & $\begin{array}{c}17 \\
\text { tahu } \\
\mathrm{n}\end{array}$ & III & $\begin{array}{l}\text { Pemilih } \\
\text { pemula }\end{array}$ \\
\hline 6 & $\begin{array}{l}\text { Yulia Lestari } \\
\text { Bancin }\end{array}$ & $\begin{array}{l}\text { Perem } \\
\text { puan }\end{array}$ & $\begin{array}{c}17 \\
\text { tahu } \\
n\end{array}$ & V & $\begin{array}{l}\text { Pemilih } \\
\text { pemula }\end{array}$ \\
\hline 7 & $\begin{array}{l}\text { Putra } \\
\text { Kurniawan }\end{array}$ & $\begin{array}{l}\text { Laki- } \\
\text { laki }\end{array}$ & $\begin{array}{c}17 \\
\text { tahu } \\
n \\
\end{array}$ & VI & $\begin{array}{l}\text { Pemilih } \\
\text { pemula }\end{array}$ \\
\hline 8 & $\begin{array}{l}\text { Dedy } \\
\text { Armansyah } \\
\text { Pakpahan }\end{array}$ & $\begin{array}{l}\text { Laki- } \\
\text { laki }\end{array}$ & $\begin{array}{c}17 \\
\text { tahu } \\
n\end{array}$ & $\begin{array}{l}\text { VI } \\
\text { I }\end{array}$ & $\begin{array}{l}\text { Pemilih } \\
\text { pemula }\end{array}$ \\
\hline
\end{tabular}

Sumber: Data Olahan Penulis tahun 2014 


\section{Defenisi Konsep}

Defenisi konsep dari masing-masing variabel dalam penelitian ini adalah sebagai berikut:

1. Partisipasi politik adalah keterlibatan individu atau kelompok sebagai warga negara dalam proses politik yang berupa kegiatan yang positif dan dapat juga yang negatif yang bertujuan ikut serta secara aktif dalam kehidupan politik dalam rangka mempengaruhi kebijakan pemerintah.

2. Pemilu Legislatif adalah pemilihan untuk memilih anggota Dewan Perwakilan Rakyat (DPR), Dewan Perwakilan Daerah (DPD), Dewan Perwakilan Rakyat Daerah (DPRD) Provinsi dan Dewan Perwakilan Rakyat Daerah (DPRD) Kabupaten/Kota yang dilaksanakan secara langsung, umum, bebas, rahasia, jujur dan adil dalam Negara Kesatuan Republik Indonesia berdasarkan Pancasila dan UndangUndang Dasar Republik Indonesia Tahun 1945.

3. Pemilih pemula adalah warga negara Indonesia berusia 17 tahun dan sudah/pernah kawin yang di daftar penyelenggara pemilu dalam daftar pemilih dan baru mengikuti (memberikan suara) pertama kali dalam pemilu.

Operasionalisasi konsep ini kemudian dijadikan sebagai instrumeninstrumen pertanyaan dalam bentuk wawancara untuk mendapatkan data yang sesungguhnya tentang Partisipasi Politik Pemilih Pemula dalam Pemilihan Umum Legislatif Tahun 2014 di Kelurahan Panyanggar Kecamatan Padangsidimpuan Utara Kota Padangsidimpuan.

\section{Teknik Pengumpulan Data}

Data yang terkumpul dalam penelitian ini terdiri dari data primer dan data sekunder dengan perincian sebagai berikut:

a. Data Primer diperoleh melalui:

1. Observasi

Observasi diartikan sebagai pengamatan dan pencatatan secara sistematik terhadap gejala yang tampak pada objek penelitian.

2. Wawancara
Wawancara merupakan teknik pengumpulan data dengan cara mengadakan tanya jawab langsung kepada orang-orang yang dianggap dapat memberikan penjelasan langsung ataupun data sebagai pelengkap penulisan ini.

b. Data Sekunder diperoleh melalui:

Data sekunder di peroleh dari dokumen-dokumen data statistik, bukubuku dan literatur lainnya yang ada kaitannya dengan objek penilitian yang penulis lakukan.

\section{Teknik Analisis Data}

Teknik analisa yang digunakan adalah teknik analisa data kualitatif. Teknik analisa data kualitatif adalah teknik yang didasarkan atas kemampuan nalar penulis dalam menginterprestasikan fakta, data dan informasi. Teknik analisa data kualitatif menyajikan data kualitatif yang dikumpulkan melalui teknik pengumpulan data kualitatif seperti hasil wawancara dengan informan dan hasil dari dokumentasi. Data yang diperoleh melalui teknik pengumpulan data selanjutnya diolah, diteliti, dan kemudian diberi interprestasi yang secukupnya sesuai dengan tujuan penelitian yang telah dirumuskan sebelumnya.

\section{Pembahasan}

Miriam Budiarjo menyebutkan partisipasi politik adalah kegiatan seseorang atau sekelompok orang untuk ikut serta secara aktif dalam kehidupan politik, dengan jalan memilih pimpinan negara dan secara langsung atau tidak langsung mempengaruhi kebijakan pemerintah. Kegiatan ini mencakup tindakan seperti memberikan suara dalam pemilihan, mengahadiri rapatt umum, menjadi anggota suatu partai atau kelompok kepentingan, mengadakan hubungan dengan pejabat atau anggota parlemen. Berdasarkan Undang-Undang Dasar Republik Indonesia Tahun 1945 Bab I pasal 1 ayat 2 menyebutkan kedaulatan berada di tangan rakyat dan dilakukan menurut Undang-Undang Dasar, dalam 


\section{Junnal Ilemial \\ MUQODDIMAH}

demokrasi modern yang menjalankan kedaulatan itu adalah wakil-wakil rakyat yang ditentukan sendiri oleh rakyat.

Pemilu legislatif secara langsung ini merupakan salah satu perwujudan partisipasi politik rakyat. Partisipasi politik itu sendiri dapat dijabarkan dalam bentukbentuk aktifitas politik yang dilakukan oleh rakyat. Kini pemilih pemula menjadi salah satu bagian dalam menentukan terpilinnya siapa anggota legislatif yang akan membawa aspirasi mereka ke ruang sidang.

Berkaitan dengan pemilu legislatif tahun 2014 di Kelurahan Panyanggar, masyarakat secara umum begitu antusias dalam memberikan hak pilihnya dalam pemilu legislatif tahun 2014 ini. Hal ini dapat dibuktikan berdasarkan hasil observasi pada hari pemungutan suara dan wawancara yang dilakukan terhadap informan penelitian menunjukkan bahwa hampir semua informan menggunakan hak pilihnya dalam pemilihan legislatif tahun 2014. Mereka melakukannya dengan berbagai alasan antara lain karena hal ini merupakan pengalaman yang pertama kali yang mereka lakukan dalam pemilu sehingga mereka sangat bersemangat untuk turut serta terlibat dalam pemilu.

Pendidikan politik masyarakat termasuk pemilih pemula dapat dilihat dari aktifitas politik maupun pengetahuan politik mereka. Dari hasil wawancara dengan informan, mereka mengungkapkan bahwa mereka hanya mengetahui syarat sebagai pemilih apabila sudah berusia minimal 17 tahun, dan mengetahui bahwa mereka sudah tercatat sebagai pemilih karena mendapatkan undangan yang diberikan anggota Kelompok Penyelenggara Pemungutan Suara (KPPS).

Meskipun pemilih pemula antusias dalam menggunakan hak pilih mereka, namun sebagian besar informan tidak mengetahui apa saja tahapan pemilu legislatif tahun 2014 dengan alasan mereka menganggap hal itu tidak begitu penting. Kurangnya pengetahuan pemilih pemula tentang tahapan pemilu ini disebabkan salah satunya faktor pendidikan pemilih pemula yang kurang mengenai masalah politik.
Diskusi politik merupakan salah satu bentuk partisipasi politik yang mudah untuk dilakukan oleh semua orang, dari diskusi tersebut masing-masing dari mereka dapat mengeluarkan pendapat atau pola pikir seseorang serta sikapnya terhadap masalah politik sehingga dapat menambah pengetahuan mengenai politik. Namun demikian tidak semua orang dapat melakukannya, karena dalam kenyataannya memang hanya pemilih pemula tertentu saja yang suka membicarakan masalah politik.

Menurut pendapat penulis, dapat dikatakan bahwa pemilih pemula memang kurang berminat pada masalah politik. Hal ini disebabkan banyak faktor, diantaranya faktor lingkungan tempat tinggal dan tingkat pendidikan yang dapat mempengaruhi minat seseorang. Pemilih pemula yang tinggal di lingkungan masyarakat yang kesadaran politiknya tinggi akan mempengaruhinya minatnya dalam membicarakan bahkan ikut ambil bagian dalam sesuatu yang berkaitan dengan politik.

Berikutnya pengetahuan pemilih pemula di Kelurahan Panyanggar terhadap tata cara pemberian suara yang dilakukan di Tempaat Pemungutan Suara (TPS) dilihat dari hasil wawancara dengan informan, mereka mengungkapkan bahwa mereka mengetahui tata cara pemberian suara pada pemilu legislatif tahun 2014. Meskipun sebagian besar dari mereka tidak mengikuti sosialisasi yang diadakan oleh Komisi Pemilihan Umum. Kurangnya kesadaran mereka untuk mengikuti sosialisasi tentang pemilu disebabkan ketidaktahuan mereka bahwa ada kegiatan sosialisasi yang diadakan Komisi Pemilihan Umum, namun ada juga dari mereka yang meskipun tahu ada kegiatan sosialisasi tersebut mereka menganggap hal itu tidak begitu penting.

Kampanye pemilu merupakan sarana pesta demokrasi, dimana organisasi peserta pemilu melaksanakan kegiatan untuk mempengaruhi pemilih dalam rangka memperoleh suara sebanyak-banyaknya dalam pemilu legislatif. Ada berbagai cara yang dilakukan oleh para calon anggota legislatif untuk menarik simpatik masyarakat seperti pawai, panggung 
terbuka, serta pemberian bantuan pembangunan tempat ibadah maupun bantuan sembako. Bagi pemilih pemula di Kelurahan Panyanggar secara keseluruhan sudah mengetahui tujuan kampanye dan mereka beranggapan bahwa kampanye merupakan suatu kegiatan menyampaikan informasi dan menunjukkan visi, misi dan program partai politik dalam pemilu sehingga menarik simpatik masyarakat untuk memilihnya.

Berdasarkan hasil wawancara dengan informan (Yulia), mengungkapkan bahwa menurutnya kampanye itu tidak perlu. Anggapan pemilih pemula bahwa kampanye merupakan kegiatan yang menyita waktu dan karena kesibukan mereka sehari-hari mengakibatkan para pemilih pemula enggan untuk ikut berpartisipasi dalam kegiatan kampanye.

\section{Hasil Wawancara}

Sesuai dengan topik penelitian yakni partisipasi pemilih pemula dalam pemilu legislatif tahun 2014 di Kelurahan Panyanggar Kecamatan Padangsidimpuan Utara Kota Padangsidimpuan, maka untuk menjawab rumusan masalah dilakukan wawancara terhadap informan yang ditentukan dengan sengaja.

1. Apakah saudara menggunakan hak pilih dalam pemilu legislatif tahun 2014 ?

Hasil wawancara dengan Nur Asiah Harahap sebagai pemilih pemula di Kelurahan Panyanggar mengatakan "ya, karena saya baru pertama kali memilih di tahun 2014 ini".

Hal yang sama juga diungkapkan oleh Yulia Lestari yang mengatakan "ya, karena saya ya mungkin saya baru pertama kali ikut acara pemilihan ini makanya saya ingin bersemangatsemangat ria untuk memilih calon legistlatif tahun ini".

Sedangkan hasil wawancara dengan Dedy Armansyah mengatakan "ya, karena saya disuruh untuk memilih, begitu saja kira-kira".

Selanjutnya wawancara dengan Edo Salsabila Nasution mengatakan "ya, karena saya baru pertama kali mengikuti pemilu legislatif jadi saya penasaran ingin merasakan

bagaimana

rasanya

mencoblos".

Kemudian hal yang berbeda diungkapkan oleh Putra Kurniawan dalam wawancara yang mengatakan "tidak, saya tidak ikut mencoblos, karena menurut saya itu tidak begitu penting. Kalaupun saya ikut tetap tidak ada perubahan disini".

Dari jawaban para informan di atas dapat disimpulkan bahwa antusias pemilih pemula dalam menggunakan hak pilinnya pada pemilu legislatif 2014 sangat tinggi. Hal ini dibuktikan bahwa mereka beranggapan jika menggunakan hak pilih merupakan pengalaman pertama jadi tidak mungkin untuk dilewatkan. Namun ada juga yang beranggapan bahwa hal itu tidak begitu penting sehingga dia tidak ikut menggunakan hak pilihnya.

2. Apakah saudara mengetahui syarat sebagai pemilih serta bagaimana anda mengetahui bahwa saudara terdaftar sebagai pemilih ?

Berdasarakn hasil wawancara penulis dengan Nur Asiah Harahap mengatakan "iya, berusia 17 tahun dan mempunyai pikiran yang waras, saya mengetahuinya karena anggota KPPS datang kerumah memberikan undangan untuk memilih disitulah saya tahu bahwa saya sudah terdaftar sebagai pemilih".

Kemudian Yulia Lestari mengatakan "ya, oh mungkin umurnya yah 17-an tahun terus sudah dewasa, berakal baligh, dan berfikiran jernih. Ya seperti yang saya ketahui saya mendapatkan surat undangan dari KPPS dari situlah saya mengetahui saya termasuk sebagai pemilih dalam pemilihan anggota legislatif tahun ini".

Selanjutnya Dedy Armansyah mengatakan "yang saya tahu syarat sebagai pemilih itu kurang lebih berumur 17 tahun, saya tahu karena dari undangan yang telah diberikan oleh anggota KPPS".

Selain itu Edo Salsabila mengatakan "yang saya tahu mungkin karena udah umur 17 tahun jadi bisa ikut memilih, saya dapat surat undangan dari panitia itu, dari situlah saya tahu kalau saya terdaftar".

Kemudian diperkuat Putra Kurniawan mengatakan "saya tahu syarat pemilih itu jika sudah berumur 17 tahun dan 
saya tahu saya terdaftar karena saya sudah berumur 17 tahun".

Dari jawaban seluruh informan dapat disimpulkan bahwa mereka mengetahui syarat sebagai pemilih hanya yang sudah berusia 17 tahun, serta mereka mengetahui bahwa mereka terdaftar karena mendapat undangan dari anggota Kelompok Penyelenggara Pemungutan Suara (KPPS).

3. Apakah saudara mengetahui apa saja tahapan pemilu legislatif tahun 2014 ?

Hasil wawancara dengan Nur Asiah Harahap mengatakan "tidak terlalu tahu karena saya baru pertama kali memilih dan saya belum mengetahui tahapan-tahapan yang ikut dalam memilih ini".

Selanjutnya Yulia Lestari mengatakan "tidak, saya sama sekali tidak mengetahui apa tahapan pemilu itu."

Kemudian Dedy Armansyah mengatakan "tidak, saya tidak tahu dan tidak mau tahu."

Selanjutnya Edo Salsabila mengatakan "tentu tidak, karena ini kan pertama kalinya saya ikut pemilu jadi saya tidak mengerti tahapan-tahapan dalam pelaksanaan pemilu legislatif itu."

Selain itu menurut Putra Kurniawan "mungkin yang saya tahu dalam pemilu itu ada namanya kampanye, itu saja."

Dari hasil jawaban informan di atas dapat disimpulkan bahwa sebagian besar dari pemilih pemula di Kelurahan Panyanggar tidak mengetahui apa saja tahapan dalam pemilu legislatif 2014 hal ini karena alasan mereka baru pertama kali ikut memilih.

4. Apakah saudara mengetahui tata cara pembertian suara pada pemilu legislatif tahun 2014 ?

Hasil wawancara dengan Nur Asiah Harahap mengatakan,

Tahu, yang pertama datang ke TPS yang kedua kita memberi undangan kepada panitia KPPS dan lalu panitia KPPS memberi surat suara yang berisi foto-foto yang calon anggota legislatif dan kita memilih salah satu yang dimana mau kita pilih lalu memasukkannya ke koyak suara, habis itu kita membikin tanda di jari kelingking bahwa kita sudah ikut memilih.

Kemudian hal yang sama diungkapkan Yulia Lestari yang mengatakan,

Yang saya ketahui kita datang ke TPS lalu menyerahkan kartu undangan kepada panitia setelah itu kartu undangan kita ditukar dengan surat suara setelah itu kita pun mencoblos anggota legislatif pilihan kita lalu memasukkannya ke kotak suara dan kita pun memberikan tanda tinta bahwa kita bahwasanya kalau kita sudah memilih.

Pendapat lain menurut Dedy Armansyah "tata cara yang saya ketahui mungkin ditusuk."

Selanjutnya Edo Salsabila mengatakan "yang saya tahu kita datang ke TPS menukar undangan yang diberikan panitia KPPS dengan surat suara lalu mencoblosnya dan mencelupkan jari ke tinta sebagai tanda kalau sudah memilih".

Selain itu Putra Kurniawan mengatakan "yang saya tahu itu dicoblos".

Dari keseluruhan jawaban informan di atas dapat disimpulkan bahwa mayoritas pemilih pemula sudah mengetahui bagaimana tata cara pemberian suara pada pemilu legislatif tahun 2014.

5. Apakah menurut saudara perlu diadakannya kampanye dan apakah anda mengikuti kampanye terbuka maupun tertutup pada pemilu legislatif tahun 2014 ?

Hasil wawancara dengan Nur Asiah Harahap mengatakan "perlu, supaya yang mau dipilih itu bisa memperkenalkan dirinya dan mengetahui apa visi misi anggota legislatif. Tidak karena urusan sangat banyak dan tidak sempat untuk ikut yang seperti itu".

Hal tersebut bertolak belakang dengan pernyataan Yulia Lestari yang mengatakan, 
Tidak, menurut saya kampanye hanya buang-buang waktu masyarakat, seperti yang kita ketahui masyarakat akhir-akhir ini dan pada tahun ini semuanya pada kurang kurang mampu, lah dan terus disitukan anggota lesgislatif hanya memperkenalkan dirinya untuk mempertunjukkan dirinya kepada masyarakat agara masyarakat memilih dia dan disitu juga para anggota legislatif memberikan suapan kepada masyarakat seperti sembako, uang, dan disitulah masyarakat tergoda dengan kekayaan ataupun suapan yang diberikan oleh anggota legislatif dan tidak bnerfikir lagi untuk memilih anggota yang lain. Tidak alasannya bagi saya itu buang waktu saja, lagian yah kerja saya masih banyak terus entar pun dia habis menang gitu dia juga gak ingat kok sama yang milih-milih dia.

Selanjutnya Dedy Armansyah mengatakan "perlu agar masyarakat tahu bagaimana visi misi anggota caleg tersebut ke depannya. Tidak karena saya tidak mau ikut-ikutan".

Selain itu Edo Salsabila mengatakan "itu sangat perlu karena jika dia tidak kampanye kita tidak tahu siapa dia dan apa visi misinya ke depan, Saya tidak mengikuti kampanye".

Hal tersebut diperkuat oleh Putra Kurniawan yang mengatakan "iya itu perlu dari kampanye itulah kita bisa tahu apa saja program dan visi misi caleg tersebut. Saya tidak ikut kampanye".

Dari jawaban informan di atas dapat disimpulkan bahwa sebagian dari mereka beranggapan bahwa kampanye itu sangat penting bagi calon anggota legislatif sebagai sarana memperkenalkan dirinya dan visi misinya. Sehingga masyarakat mau memilih dia namun ada juga yang beranggapan bahwa kampanye itu tidak perlu karena menurutnya hal itu hanya buang-buang waktu saja.
6. Apakah saudara mengikuti sosialisasi tentang pemilu legislatif tahun 2014 yang diadakan oleh Komisi Pemilihan Umum (KPU) ?

Hasil wawancara dengan Nur Asiah Harahap mengatakan "tidak, saya tidak tahu bahwa diadakannya sosialisasi oleh KPU."

Kemudian Yulia Lestari mengatakan "tidak karena saya tidak pernah mengetahui tentang sosialisasi pemilu legisitaif tahun 2014 ini."

Selain itu Dedy Armansyah mengatakan "tidak, itukan sudah ada petugasnya, saya tidak ikut-ikutan."

Hal berbeda diungkapkan Edo Salsabila mengatakan "ya saya ikut sosialisasi itu kemaren karena lokasi sosialisasi tepat berada di dekat rumah saya".

Selanjutnya Putra Kurniawan mengatakan "saya tidak tahu bahwa ada sosialisasi kalau pun saya tahu mungkin saya juga malas untuk mengikutinya".

Dari hasil wawancara dengan informan dapat disimpulkan bahwa sebagian besar dari mereka tidak mengikuti sosialisasi yang diadakan oleh KPU karena ketidaktahuan mereka kapan diadakannya sosialisasi tersebut namun ada juga yang ikut mengahadiri sosialisasi karena lokasi pelaksanaan sosialisasi berdekatan dengam rumahnya.

7. Bagaimana antusias pemilih pemula pada pemilu legislatif tahun 2014 ?

Hasil wawancara dengan Milfa Suryani Harahap sebagai Ketua Kelompok Penyelenggara Pemungutan Suara (KPPS) mengatakan "pemilih sangat bersemangat untuk menentukan pilihannya, dimana dalam pemilihan ini tidak ada unsur paksaan dalam memilih".

Dari jawaban informan diatas dapat disimpulkan bahwa antusias pemilih pemula dalam pemilu legislatif tahun 2014 cukup tinggi, hal ini terlihat berdasarkan jumlah pemilih pemula yang ikut menggunakan hak pilinnya.

8. Berapa jumlah pemilih pemula keseluruhan dan jumlah pemilih pemula yang menggunakan hak pilihnya dalam pemilu legislatif 2014 ?

Hasil wawancara dengan Evi Harahap mengatakan "jumlah pemilih pemula secara keseluruhan saya tidak tahu secara pasti angkanya namun yang saya lihat hamper keseluruhan pemilih pemula di 
Kelurahan Panyanggar ikut menggunakan hak pilihnya".

Hal berbeda diungkapkan Milfa Suryani Harahap yang mengatakan "jumlah keseluruhan pemilih pemula yang berusia 17 tahun adalah 122 orang, yang dibagi dalam 9 TPS dan yang menggunakan hak pilihnya dalam pemilu sekitar 114 orang".

Dari jawaban informan diatas dapat disimpulkan bahwa dari keseluruhan jumlah pemilih pemula yang ada di Kelurahan Panyanggar, hampir semua dari mereka datang ke tempat pemungutan suara untuk menggunakan hak pilihnya dalam pemilu legislatif tahun 2014.

9. Apakah saudara mengadakan sosialisasi peraturan dan tata cara pemberian suara dalam pemilu legislatif tahun 2014 kepada masyarakat?

Hasil wawancara dengan Muktar

Helmi mengatakan,

Sosialisasi yang kita lakukan itu yang pertama KPU dan jajarannya mendatangi sekolah-sekolah dan kita melakukan MOU dengan Dinas Pendidikan dan Kemenag Kota Padangsidimpuan agar kita bisa terjun langsung ke sekolah. Kemudian di SMK 1 kita melakukan yang namanya celup jari, dimana itu anak-anak SMK 1 saat itu melakukan peragaan bagaimana cara memilih yang benar dan tepat. Kemudian KPU Kota Padangsidimpuan juga bersosialisasi tentang pemilu legislatif ini baik melalui spanduk, melalui iklan di surat kabar metro tabagsel, kemudian melalui radio yaitu radio Kiss $\mathrm{fm}$ Kota Padangsidimpuan. Sosialisasi ini dilakukan untuk mengajak dan memberikan pembelajaran politik kepada pemilih pemula sehingga benar-benar tahu bagaimana cara menggunakan hak ilihnya dan mereka juga belajar tentang track record calon legislatif yang akan mereka pilih.

Selanjutnya Evi Harahap mengatakan Ya, kami mengadakan sosialisasi di gedung UMTS pada tanggal 5 April 2014 bersama seluruh pengurus yang ada di Kota padangsidimpuan dan pada tanggal 7 April 2014 kembali dilaksanakan sosialisasi di Kelurahan Panyanggar Lingkungan I bersama masyarakat Panyanggar dan para petugas KPPS. Sosialisasi yang dilakukan adalah tentang bagaimana cara memilih yang benar"

Dari jawaban informan dapat disimpulkan bahwa Panitia Pemungutan Suara (PPS) maupun Kelompok Penyelenggara Pemungutan Suara (KPPS) telah melaksanakan sosialisasi tentang peraturan dan tata cara pemberian suara pada pemilu legislatif tahun 2014 kepada masyarakat di Kelurahan Panyanggar.

10. Apakah ada kendala yang dialami pemilih pemula dala menggunakan hak pilihnya?

Evi Harahap mengatakan "iya ada, itu kendalanya mereka bingung yang mana yang mau dicoblos"

Selanjutnya Milfa Suryani Harahap mengatakan "pastinya ada kendala, pemilih pemula masih kebingungan tentang cara mencoblos yang benar dan karena yang dipilih itu bukan 1 (satu) surat suara, tetapi ada 4 (empat) surat suara, jadi mereka bingung yang mana caleg yang akan dipilih."

Dari jawaban informan di atas dapat disimpulkan bahwa masih terdapat kendala yang dialami pemilih pemula dalam pemberian suara, hal tersebut akibat kebingungan pemilih pemula tentang bagaimana cara mencoblos yang benar dan menentukan pilihan dari keempat surat suara yang ada.

\section{KESIMPULAN DAN SARAN}

\section{Kesimpulan}

Dari hasil penelitian ini didapatkan bahwa partisipasi pemilih pemula sangat aktif dalam pemilu legislatif tahun 2014 di Kelurahan Panyanggar Kecamatan Padangsidimpuan Utara Kota Padangsidimpuan dimana pemilih pemula sangat antusias untuk ikut mengunakan hak pilihnya hal ini dapat dibuktikan dari persentase kehadiran pemilih pemula dalam pemilu legislatif hampir 94,3 \% dari mereka datang ke 
Tempat Pemungutan Suara (TPS) untuk memilih calon anggota legislatif pilihannya.

\section{Saran}

Adapun saran yang penulis ajukan terkait partisipasi pemilih pemula dalam pemilu legislatif tahun 2014 di Kelurahan Panyanggar Kecamatan Padangsidimpuan Utara Kota Padangsidimpuan adalah

1. Pemilih pemula hendaknya dapat lebih membuka diri untuk aktif dalam berbagai kegiatan politik.

2. Melakukan optimalisasi pendidikan politik (KPU) terhadap pemilih pemula untuk dapat merangsang keinginan mereka berpartisipasi dalam kegiatan politik.

\section{Daftar Pustaka}

Buku:

Agustino, Leo, 2007, Perihal IImu Politik, Sebuah Bahasan Memahami IImu Politik. Yogyakarta: Graha IImu.

Arifin, Anwar, 2011, Komunikasi Politik, Filsafat-Paradigma-Teori-TujuanStrategi dan Komunikasi Politik Indonesia. Yogyakarta: Graha IImu.

Budiarjo, Miriam, 2008, Dasar-Dasar IImu Politik. Jakarta: Gramedia Pustaka Utama.

Kumorotomo, Wahyudi, 2008, Etika Administrasi Negara. Jakarta: PT. Raja Grafindo Persada.

Rahman, A.H.I, 2007, Sistem Politik Indonesia. Yogyakarta: Graha IImu.

Sitepu, P.Antonius, 2012, Studi Ilmu Politik. Jakarta: Graha Ilmu.

Modul KPU (Modul 1 Pemilih Untuk Pemula).

Modul A.3 KPU Daftar Pemilih Tetap Pemilihan Umum Anggota DPR, DPD, DPRD Provinsi dan DPRD Kabupaten/Kota Tahun 2014
Undang-Undang:

Undang-Undang Dasar Republik Indonesia Tahun 1945.

Undang-Undang Republik Indonesia Nomor 15 Tahun 2011 tentang Penyelenggaraan Pemilihan Umum.

Undang-Undang Republik Indonesia Nomor 8 Tahun 2012 tentang Pemilihan Umum Anggota Dewan Perwakilan Rakyat, Dewan Perwakilan Daerah, Dewan Perwakilan Rakyat Daerah.

Undang-Undang Nomor 2 Tahun 2011 tentang Partai Politik.

Peraturan Komisi Pemili m Nomor
7 Tahun 2012 ciıaır Tahapan,
Program, Dan Jadual
Penyelenggaraan Pemilihan Umum
Anggota Dewan Perwakilan Rakyat,
Dewan Perwakilan Daerah, Dan
Dewan Perwakilan Rakyat Daerah
Tahun 2014.

7 Tahun 2012 cmany Tahapan, Program, Dan Jadual Penyelenggaraan Pemilihan Umum Anggota Dewan Perwakilan Rakyat, Dewan Perwakilan Rakyat Daerah 